This item was submitted to Loughborough's Research Repository by the author.

Items in Figshare are protected by copyright, with all rights reserved, unless otherwise indicated.

\title{
The illegal, the missing: An evaluation of conceptual inventions
}

\section{PLEASE CITE THE PUBLISHED VERSION}

https://doi.org/10.1177/0305829817708812

\section{PUBLISHER}

(C) The Authors. Published by SAGE Publications (UK and US)

\section{VERSION}

AM (Accepted Manuscript)

\section{PUBLISHER STATEMENT}

This work is made available according to the conditions of the Creative Commons Attribution-NonCommercialNoDerivatives 4.0 International (CC BY-NC-ND 4.0) licence. Full details of this licence are available at: https://creativecommons.org/licenses/by-nc-nd/4.0/

\section{LICENCE}

CC BY-NC-ND 4.0

\section{REPOSITORY RECORD}

Oelgemoller, Christina. 2017. "The Illegal, the Missing: An Evaluation of Conceptual Inventions". Loughborough University. https://hdl.handle.net/2134/24665. 


\title{
The Illegal, The Missing: An Evaluation of Conceptual Inventions
}

\author{
Abstract \\ Migration Management, a regime of radical differentiation and exclusion, renders \\ many people illegal because they violate the laws of access across geopolitical \\ borders. Migration Management further disappears some of these illegal people \\ outside of the external boundaries of the Global North. Recently, however, \\ discursive moves to mobilise the concept of the 'missing person' in the context of \\ illegal migration have been introduced when discussing Mediterranean migration \\ in particular. This article offers an ethico-political evaluation of conceptual \\ innovations. It asks if a reconceptualisation of the illegal migrant as 'missing \\ person' is able to destabilise Migration Management and concludes that this is \\ unlikely. The article illustrates how this reconceptualisation cements the more \\ radical practices of exclusion whilst the boundary drawing is reformulated as one \\ between dead and living migrants.
}

\section{Key words}

missing persons, illegal migration, death, political subjectivity, boundaries, juridico-technological mechanisms 


\section{Introduction}

On 3 October 2013, a boat loaded with an estimated 500 migrants travelling from Africa to Europe caught fire, capsized and sank. A few days later the capsizing of another boat resulted in more death. ${ }^{1}$ Since then, news media have regularly reported the deaths of 'illegal migrants' in the Mediterranean. In the wake of the 3 October drownings, the European Union (EU), represented by its then home affairs commissioner Cecilia Malmstroem, tweeted: 'Appalled by Lampedusa tragedy. Thoughts are with victims and families.' ${ }^{2}$ These are largely unidentified individuals. Malmstroem went on: 'We must redouble efforts to fight smugglers exploiting human despair.'3 A Spanish newspaper article entitled 'Only the dead can stay'4 reported that the Italian Prime Minister had announced that all the deceased would receive Italian citizenship. The unidentified dead were given a coffin and a number expressing their new citizenship, but no name. Yet the surviving 114 rescued adults were accused by the authorities of illegal migration and were to be prosecuted. ${ }^{5}$

\footnotetext{
1 'Death Toll of African Migrants Rises after Boat Disaster near Lampedusa', Guardian, 12 October 2013. Available at www.theguardian.com/world/2013/oct/12/african-migrants-boat-lampedusa-capsizesmediterranean. Accessed 16 October 2013.

2 Tweet @MalmstroemEU, 3 October 2013.

${ }^{3}$ Ibid.

${ }^{4}$ El Pais, 5 October 2013.

${ }^{5}$ P. Ordaz, 'Solo los muertos pueden quedarse', El Pais, 5 October 2013. Available at http://internacional.elpais.com/internacional/2013/10/05/actualidad/1380999528_613934.html. Accessed 22 February 2014.
} 
By coincidence, in the same month the International Commission on Missing Persons (ICMP) was consulting major donor countries, among them European countries, on its future legal standing and mandate. The ICMP is an organisation established in 1996 in reaction to the many missing persons that resulted from the war in the Balkans. Its uniqueness lies in its particular use of technology, especially DNA forensic science and database building, for identification and matching purposes. It was established to 'secure the cooperation of governments and other authorities in locating and identifying persons missing as a result of armed conflicts, human rights abuses, disasters as well as other causes' ${ }^{6}$ The expansion in mandate sought by the ICMP in 2013 explicitly formulated 'other causes' to comprise 'organized violence, including human trafficking, drug related violence, as well as persons missing from migration and displacement'. ${ }^{7}$ Another international organization recently interested in the Mediterranean 'missing migrants' is the International Organization for Migration (IOM) which runs a Global Migration Data Analysis Center (GMDAC) and as part of that a Missing

\footnotetext{
${ }^{6}$ International Commission on Missing Persons, Fact Sheet ICMP.Cos.58.9.eng.doc (n.d.). Available at: www.icmp.org/wp-content/uploads/2013/10/icmp-cos-58-10-doc-fact-sheet.pdf (accessed 22 February 2014).

${ }^{7}$ Invitation to the conference 'The Missing: An Agenda for the Future', Doc No: 121-020/2013 (Sarajevo and The Hague: ICMP), 3 June 2013.
} 
Migrants Project. ${ }^{8}$ Alongside this project IOM has now published two volumes on the issue. ${ }^{9}$

The missing person, and especially the 'missing' migrant, has also captured interest of social science researchers. Since 2011 there has been a burgeoning literature which makes a moral argument framed within human rights law. Most recently, in 2015, the Economic and Social Research Council (ESRC) in the UK has funded a project Mediterranean Missing - Understanding Needs of Families and Obligations of States. ${ }^{10}$ This literature makes the argument that states must live up to their obligations under human rights law to effectively investigate ${ }^{11}$ the death of migrants washed ashore and that the integrity of the family needs to be upheld by providing families left behind with concrete information. ${ }^{12}$ All of these arguments point to the need that identification must be sought in order to achieve closure for

\footnotetext{
${ }^{8} \mathrm{http}: / /$ iomgmdac.org/missing-migrants-project/ [accessed 05.09.2016]

${ }^{9}$ IOM; Fatal Journeys: Tracking Lives Lost during Migration (2014) and Fatal Journeys Volume 2: Identification and Tracing of Dead and Missing Migrants (2016).

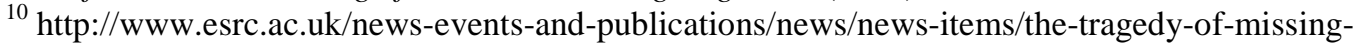
migrants-in-the-mediterranean/ [accessed 05. 09.2016] This article will not focus on the politics of neglecting the perspective of families. The focus here is the discursive practices of 'experts', by drawing on research conducted with the ICMP, the IOM and the ICRC between 2013 and 2016 and analysis of research published since 2011.

${ }^{11}$ The obligation to effectively investigate and prosecute is today accepted as international customary law, for a concrete grounding in international law see for example International Covenant on Civil and Political Rights, Art 2(3), see also European Convention for the protection of Human Rights and Fundamental Freedoms, Art 13

${ }^{12}$ J. Edkins, Missing: Persons and Politics (Ithaca, NY: Cornell University Press, 2011); K. T. Jones, K. S. Zagacki, and T. V. Lewis, 'Communication, Liminality, and Hope: The September 11th Missing Person Posters', Communication Studies 58, no. 1 (2007): 105-21; P. Boss, 'Ambiguous Loss in Families of the Missing', Lancet 360 (suppl.) (2002): 39-40; A. Kelly, 'Living Loss: An Exploration of the Internal Space of Liminality', Mortality: Promoting the Interdisciplinary Study of Death and Dying 13, no. 4 (2008): 335-50.
} 
those left behind and for the state to retain an orderly system of accounting for juridico-political status of citizens and non-citizens. ${ }^{13}$

Drawing on the above observations, the objective of this article is to identify a process of conceptual innovation that seems to be appearing, in which a proximity is established between the illegal migrant and the missing person, and to think through the impact this conceptual innovation might plausibly have. Deleuze and Guattari argue that concepts are self-positing (expressive) entities that are defined by internal consistency between their elements and in conjunction with a concept's relation to other concepts. ${ }^{14}$ Concepts are also historical constructs, which change according to fluctuations in time and context. In other words, concepts are necessary for thinking; however, they are also distinctly undecidable. ${ }^{15}$ Thus, concepts are open to transformation, or as in this case to innovation. ${ }^{16}$ At the point where elements of two concepts are brought into proximity, the possibility for becoming new is constituted.

\footnotetext{
${ }^{13}$ F. Stepputat, Governing the Dead: Sovereignty and the Politics of Dead Bodies. (Manchester: Manchester University Press, 2014). See also for another project, the Vrije Universiteit Amsterdam which focuses on dead/missing migrants in its Human Costs of Border Control project, www.borderdeaths.org [accessed 25 February 2016]

${ }^{14}$ G. Deleuze, and F. Guattari. What is philosophy?. Columbia University Press, 2014.

${ }^{15}$ J. Derrida. Limited inc. Vol. 10. Northwestern University Press, 1977.

${ }^{16}$ A wide variety of possible theoretical approaches to the study of concepts are available. Given the broadly poststructuralist framing within which this article is situated I am informed by a Derridian approach as read by Deleuze/Guatarri.
} 
It seems - given the empirical context illustrated above - that, the discursive ambitions to introduce conceptual innovation are motivated in this case by a drive for stability felt to be undermined by dying migrants on the one hand; and a humanitarian instinct ${ }^{17}$ to identify the unidentified migrant (or 'missing person') on the other. What seems to motivate the above listed actors involved in the conceptual innovation is to bring a more unambiguously enforced rights-based approach to bear on the violent traits of Migration Management, forcing the authorities to be accountable for what are called 'unintended consequences'.

However, I argue that the reconceptualization of migrants as missing persons is ultimately unable to de-stabilize the perverse effects of the management of illegal migrants. The reconceptualization of the illegal migrant as a 'missing person' not only domesticates and governs this particular political subjectivity, but is also capable of endangering illegal migrants further because of the conceptual move that renders dead migrants both intelligible and incorporable into the 'normal' order. The proximity of conceptual elements is established in the dead migrant via juridico-technological mechanisms: the dead migrant is mournable but not politically active and thus non-threatening. This means that a new boundary is

\footnotetext{
${ }^{17}$ By 'humanitarian instinct' I understand the rather simplistic sense and expression of empathy with suffering, for a deeper discussion cf D. Fassin. Humanitarian reason: a moral history of the present. Univ of California Press, 2012. or M. Agier. "Humanity as an identity and its political effects (a note on camps and humanitarian government)." Humanity: An International Journal of Human Rights, Humanitarianism, and Development 1, no. 1 (2010): 29-45.
} 
established, between the migrant who is alive and invested with political subjectivity and the migrant who is dead. Yet, this new boundary is not capable of challenging either violent exclusion or the negligence inherent in the discourse of Migration Management.

The argument is elaborated in four steps: First, I briefly introduce the two fields of knowledge, that of international migration and that of missing persons, which converge to form the conceptual innovation. The former is guided by an assumption of life; the latter is guided by an assumption of death. Both fields of knowledge have in common that the phenomena pose a problem for societal stability and thus have to be contained. Second, I offer some thoughts and illustration of how this conversion is discursively achieved such that reconceptualization is possible and the concept of the missing migrant can evolve. Third, I then ask if such a reconceptualization can destabilize the management of the illegal migrant by forcing recognition of negligence on the part of European Union governments in their policy enforcement. ${ }^{18}$ In the last step, I argue that as a result of reconceptualization, migrants are not missing; rather, some have been exposed to death, killed by willful neglect. The term 'missing', then, can be used as a euphemism that erases the abandonment effected by the (European) Migration

\footnotetext{
${ }^{18}$ I. Ashutosh and A. Mountz, 'Migration Management for the Benefit of Whom? Interrogating the Work of the International Organization for Migration’, Citizenship Studies 15, no. 1 (2011): 21-38.
} 
Management regime. The political work done through such a conceptual innovation is capable of drawing a new boundary between those individuals found dead and those alive. This might make the life of those who have not died more precarious. As such, conceptual innovation cements some of the more radical practices of exclusion and normative violence.

\section{Convergence of two knowledges? Illegal Migrants and Missing}

\section{Persons}

Dead bodies are disturbing, and many of the countries which bear the brunt of finding bodies washed up on their shores are overwhelmed by the task of dealing with such bodies. Disappeared persons are all the more disturbing as there is no physicality to grasp. Jenny Edkins in her 2011 book Missing develops the critique that a government's concern with situations of mass disappearance means a focus on system order rather than making space for a politics of individual personhood with the consequence that missing persons can at best be accounted for numerically as shown in the example above. ${ }^{19}$ Moreover, there is always the possibility that someone at some point might return. ${ }^{20}$ Disappearance is unruly. In the situation currently faced in the Mediterranean, European governments do their

\footnotetext{
${ }^{19}$ Edkins, Missing, p.7

${ }^{20}$ Ibid, p. 12
} 
best to manage (illegal) migration out of existence while scores of people die and disappear. Re-conceptualizing migrants as missing persons seems attractive, as it might de-stabilise some of the more perverse effects of Migration Management.

Politically, this re-conceptualization is important as forensic technologies are called for to trace and identify 'migrants' as 'missing', thus promising to re-capture the human absence. Yet, there is no clear definition of 'missing person' in international law. ${ }^{21}$ The 'missing person' is operationalized through the use of technology and statistical probability calculations based on evidence that might be found of a person who might have been a physical fact. This operationalization is important for the discursive drive for conceptual innovations because organizations and scholars employ moral claims based on the presumption of death focussing on the 'family left behind' - on the living - not on the missing person. ${ }^{22}$ Thus, conceptually, the missing person is empty of fixed meaning.

\footnotetext{
${ }^{21}$ ICRC Guiding Principles [Art.2(1)] define a missing person as 'a person whose whereabouts are unknown to his/her relatives and/or who, on the basis of reliable information, has been reported missing in accordance with the national legislation in connection with an international or non-international armed conflict, a situation of internal violence or disturbances, natural catastrophes or any other situation that may require the intervention of a competent State authority.' Introduction to ICRC Guiding Principles 2009

22 The ICRC Guiding Principles state - inter alia - that (1) everyone has the right to know about the fate of missing relatives, including their whereabouts or, if dead, the circumstances of their death and place of burial, and to receive mortal remains (p.7); (2) the authorities must keep relatives informed about the progress and results of investigations (p.7); (3) all available means must be undertaken to recover and identify bodies and recover personal effects (p. 19); (p.21).
} 
In combination with forensics defined by Weizman as meaning 'before a forum' and referring to 'the practice and skill of making propositions through objects [e.g. the anonymised DNA of someone] before professional and political gatherings or courts of law' 23 the missing person becomes an object cum subject mediated by scientific techniques promising closure and stability disclosed in public fora. However, such closure is a myth: 'the family left in limbo' as argument seems dubious though attractive. ${ }^{24}$ Rather, the ambiguity enables space for a reconceptualization of the migrant into the missing which, in turn, enables the tighter drawing of the boundary between dead migrants for whom charity can be felt as subjects of the past turned controllable object and those who live, those who are securitised.

In this section I first briefly introduce Migration Management which centres on an assumption of being alive, in a second step I then introduce 'the missing' as understood by the nascent international regime around it which centres on an assumption of death.

\section{Migration Management}

Ghosh introduced Migration Management to the international community as the 'missing regime', calling for a comprehensive regime of regulated and efficient

${ }^{23}$ E Weizman,P Tavares, S Schuppli and Situ Studio 'Forensic Architecture’ Architectural Design 80, no. 5 (2010):58-63, p. 59

${ }^{24}$ P Boss and D Carnes 'The Myth of Closure’ Family Process 51, no. 4 (2012): 456-469. 
openness vis-à-vis cross-border mobility. ${ }^{25}$ Migration Management as imagined and represented by governments, the European Union and some international organisations neatly reduces international migration to a question of legitimacy of access. ${ }^{26}$ Its legal categories serve to give the impression that migration can be managed in toto: all there is to regulate about international migration is captured, economic migration, displacement, and all cross-cutting issues such as border management or humanitarian assistance, including illegal migration. 2728

Discursively the category of 'illegal migration' defines and stabilises the discourse of Migration Management; it conjures up imaginaries of young, uneducated men who are potentially a security threat ${ }^{29}$ in that they are likely to be either criminal or at least willingly undermine European systems of social welfare and politicocommunal stability. By being deemed to be unable or unwilling to be domesticated, for example because these young men are imagined to be un-integrateable, they

\footnotetext{
${ }^{25}$ B. Ghosh, Managing Migration: Time for a New International Regime? (Oxford: Oxford University Press, 2000). Cf. M. Geiger and A. Pécoud, The Politics of International Migration Management (Basingstoke: Palgrave Macmillan, 2010).

${ }^{26}$ C. Oelgemöller, 'Informal Plurilateralism: The Impossibility of Multilateralism in the Steering of Migration', British Journal of Politics and International Relations 13, no. 1 (2011): 110-26.

${ }^{27}$ C. Oelgemöller, The Evolution of Migration Management in the Global North Oxon: Routledge, 2017.

${ }^{28}$ W. Walters, 'Foucault and Frontiers: Notes on the Birth of the Humanitarian Border', in Governmentality: Current Issues and Future Challenges, eds. U. Broeckling, S. Krasmann and T. Lemke (London: Routledge, 2011).

${ }^{29}$ Cf. D. Bigo, 'When Two Become One: Internal and External Securitisations in Europe', in International Relations Theory and the Politics of European Integration, Power, Security and Community, eds. M. Kelstrup and M. C. Williams (London: Routledge, 2000); V. Squire, ed., The Contested Politics of Mobility: Borderzones and Irregularity (Basingstoke: Palgrave Macmillan, 2011); H. van Houtum, 'Human Blacklisting: The Global Apartheid of the EU's External Border Regime', Environment and Planning D: Society and Space 28, no. 6 (2010): 957-76.
} 
need to be excluded, so as not to harm the receiving societies. ${ }^{30}$ In this process people on the move become suspended: they become conceptually disappeared as persons and hunted as an idea of something simplistically imagined as male, black, poor, and devious. ${ }^{31}$

However much criticised, ${ }^{32}$ the premise of Migration Management is domestication by juridico-political status: in this sense it is normative violence. An imaginary is turned into a norm and then enacted through policy practice. The policy practice discursively interacts with other areas of managing the international in relation to people and articulates often as either neglect or physical violence enacted by the

\footnotetext{
${ }^{30}$ Andersson shows vividly what measures the European Union and its component governments have taken since the late 1990s in particular to make 'illegal migrants' of people on the move, throughout all countries on the way to transit countries at the external borders to the EU, by which time the person on the move has metamorphosed into someone deportable and internable, whether the ultimate goal of migration was Europe or not. Andersson, Illegality, Inc. See also G. Garelli and M. Tazzioli, 'Arab Springs Making Space: Territoriality and Moral Geographies For Asylum Seekers in Italy’, Environment and Planning D: Society and Space 31, no. 6 (2013): 1,004-21.

${ }^{31}$ See also H. Lucht, 'Pusher Stories: Ghanaian Connection Men and the Expansion of the EU's Border Regimes into Africa', in The Migration Industry and the Commercialization of International Migration, eds. T. Gammeltoft-Hansen and N. Nyberg Sorensen (London: Routledge, 2013).

${ }^{32}$ Cf. L. Amoore, 'Biometric Borders: Governing Mobilities in the War on Terror', Political Geography 25, no. 3 (2006): 336-51; R. Andersson, Illegality, Inc.: Clandestine Migration and the Business of Bordering Europe (Oakland: University of California Press, 2014); D. Bigo, 'The (In)securitization Practices of the Three Universes of EU Border Control: Military/Navy - Border Guards/Police Database Analysts', Security Dialogue 45, no. 3 (2014): 209-25; H. Johnson, 'The Other Side of the Fence: Reconceptualizing the "Camp" and Migration Zones at the Borders of Spain', International Political Sociology 7, no. 1 (2013): 75-91; S. Mezzadra and S. Nielson, Border as Method: or, The Multiplication Of Labor (Durham, NC: Duke University Press, 2013; W. Walters, 'Mapping Schengenland: Denaturalizing the Border', Environment and Planning D: Society and Space 20, no. 5 (2002): 564-80.
} 
security industry. ${ }^{33}$ The illegal migrant of Migration Management has - through a denial of legal access - been conceptually disappeared.

Those who are conceptually disappeared because they have no juridico-political markers of recognition, whether they dwell in the mountainous woods of Morocco or barely exist in the desert on the way to reach Algeria, are nonetheless connected to each other, to their families and to contacts elsewhere. ${ }^{34}$ So, in this sense they are not missing. In Migration Management death is understood merely an 'unintended side effect'. ${ }^{35}$ The 'unintended side effects' which the UN Special Rapporteur on the Human Rights of Migrants referred to are justified by the hegemonic 'truth' of the professional elite discourse which accepts, repeats and normalises the view that states have the duty to regulate the movement of people to ensure that nation-states are kept secure and stable. What is relevant here is that in order for the above logic to work, the grounding assumption is that when dealing with international migrants they are alive; they are not missing, nor are they dead.

\section{Missing Persons}

\footnotetext{
33 J. Butler, Precarious Life: The Powers of Mourning and Violence (London: Verso, 2006); E. Prokkola, 'Technologies of Border Management: Performances and Calculations of Finnish/Schengen Border Security', Geopolitics 18, no. 1 (2013): 77-94.

${ }^{34}$ Andersson, Illegality, Inc.; Johnson, 'The Other Side of the Fence'; Lucht, 'Pusher Stories'.

${ }^{35}$ United Nations, Promotion and Protection of All Human Rights, Civil, Political, Economic, Social and Cultural Rights, Including the Right to Development. Report of the Special Rapporteur on the Human Rights of Migrants Jorge Bustamante A/HRC/7/12 (Geneva: Human Rights Council, 2008).
} 
Conversely, in the case of missing persons in geopolitical situations, there is an assumption of death, presumed death, on the part of the missing person, and death is seen to be the undesirable state of affairs. Death is a symptom of lack of stability, of a policy or political action gone wrong, or of neglect, especially when the death cannot be wholly accounted for in terms of the identity of the person who is dead, the circumstances in which the person died and thus the perpetrator who caused the death. ${ }^{36}$ In order to re-establish stability a juridico-technological approach is needed. Among international organizations and scholars the ICMP expresses this most clearly by drawing on the justifying logic of internationally mediated transitional justice as defined by the United Nations Security Council: as the 'full range of processes and mechanisms associated with a society's attempts to come to terms with a legacy of past abuses, in order to ensure accountability, serve justice and achieve reconciliation'. ${ }^{37}$ Relevant here is that those who are interested in a convergence between migration and missing persons positions are

\footnotetext{
${ }^{36}$ Interview with ICMP staff, June 2014. The emphasis on who is mine and points to the problem that if people have disappeared and died in contextual events such as war there is hardly ever the possibility to establish a single person as perpetrator, yet a discourse cannot be placed in front of a court of law.

${ }^{37}$ United Nations Security Council The Rule of Law and Transitional Justice in Conflict and PostConflict Societies. Report of the Secretary General S/2004/616* (2004): 4. www.ipu.org/splze/unga07/law.pdf. Accessed 25 February 2016.
} 
located on the punitive justice side of the argument in the debate about transitional justice and the achievement of stability. ${ }^{38}$

This movement towards transitional justice with its emphasis on evidencegathering, expertise and the rule of law reflects a more general dynamic of the 1990s and 2000s and is well expressed by an observation published by the ICMP in 2013: 'Law-based, forensic approaches that conform to the requirements of courts of law are becoming the norm'. ${ }^{39}$ Therefore, '[e]stablishing effective processes for locating the missing may be viewed as the newest form of transitional justice. Such processes are embedded in the right to truth,' stipulating the duty of governments to investigate abuses and atrocities. ${ }^{40}$ The construction of a juridico-political problem adds a different layer of intelligibility to the humanitarian narrative of ambiguous loss as proposed by scholars advocating for new policy initiatives. ${ }^{41} \mathrm{In}$ the case of missing persons

[an] important condition for the progress [on dealing with missing persons] relates directly to the rule-of-law approach that has been taken, including working to standards of evidence that are required in civil legal process,

\footnotetext{
${ }^{38}$ D. Groome, 'Right to Truth in the Fight against Impunity', Berkeley Journal of International Law 29 (2011): 175.

${ }^{39}$ ICMP, The Missing - An Agenda for the Future, conference report (Sarajevo/The Hague: ICMP, 2013: 10).

${ }^{40}$ Ibid.: 16; M. Koskenniemi, 'International Law and Hegemony: A Reconfiguration', Cambridge Review of International Affairs 17, no. 2 (2004): 197-218.

${ }^{41}$ Robins, S. et al. (Sept 2016) Missing Migrants in the Mediterranean: Addressing the Humanitarian Crisis - Summary report, mediterraneanmissing.eu http://www.mediterraneanmissing.eu/data/ [accessed 06 Sept 2016]
} 
criminal prosecutions, and for the purposes of issuing reliable death certificates. ${ }^{42}$

The last point in particular is relevant - the issuing of reliable death certificates to erase uncertainty. Increasingly, international organizations and scholars interested in missing persons have championed the development and spread of DNA technologies and associated institutional infrastructures in order to 'lead in the development and practices to search for the missing $[\ldots]^{\prime},{ }^{43}$ because 'uncertainty about the fate of missing persons undermines confidence in democratic and political institutions' and 'can haunt societies for generations to come'. ${ }^{44}$ Death in this context is less ambiguous and therefore easier to manage than are the inconsistencies introduced by the empirical experience of disappearance.

\section{Re-conceptualisations?}

Whereas, arguably, in war situations death is intended, in the event of international mobility geographical circumstances and policy practices create 'unintended consequences' such that European policy makers and enforcers can

\footnotetext{
${ }^{42}$ ICMP, The Missing, 7.

${ }^{43}$ Kathryne Bomberger, ICMP Director-General, in C. Jennings, Bosnia's Million Bones: Solving the World's Greatest Forensic Puzzle (Basingstoke: Macmillan 2013)

${ }^{44}$ ICMP, 'Technical Assistance' (n.d.). Available at www.icmp.org/what-we-do/technical-assistance. Accessed 5 December 2014.
} 
claim not to be responsible for those dying during the process of migration. The consequences are entirely the responsibility of the migrants, and if the implication of not conforming to efforts of domestication is disappearance or death then this is unintentional; it happens. ${ }^{45}$ The difference between these two expressions is that there is technology to deal with the living and with the dead; the disappeared stay outside of the possibility of control.

The use of juridico-technical mechanisms to reinstate control is an important element of statecraft. These mechanisms are characterised by routinized, unspectacular and continuous responses, as Huysmans puts it. ${ }^{46}$ Policy defines legal standards in positive law: regulations that differentiate between legal and illegal and between victim and perpetrator. These set the standards for the use of technology to trace, identify, quantify and construct evidence. Migration Management uses technology in its border control and identity management, whilst the newly evolving missing persons regime uses forensic and DNA technology.

The use of technology is underscored by the broader logic of (in)security and risk practices, with the focus not so much on the migrant or missing person as on the normal functioning of society and the technologies that can be used in order to

\footnotetext{
45 (Doty, 2011: 606)

46 J. Huysmans, 'What's in an Act? On Security Speech Acts and Little Security Nothings', Security Dialogue 42, nos. 4-5 (2011): 371-83.
} 
stabilise and secure this normality.$^{47}$ Bigo explains that securing is concerned with 'population profiling, risk management, statistical calculation, category creation, proactive preparation'. ${ }^{48}$ This is reflected in the approaches both to illegal migrants and to missing persons. In both instances, protocols have developed that rely on the application of routine processes and technology to trace, identify and put people 'in their place'. 49

In 2009 the governments of the European Union agreed the Stockholm Programme. Under heading 6, 'A Europe of Responsibility, Solidarity and Partnership in Migration and Asylum Matters', the European Council states that ‘[a]n important objective is to avoid the recurrence of tragedies at sea. When tragic situations unfortunately happen ways should be explored to better record and, where possible, identify migrants trying to reach the Union'. ${ }^{50}$ This is interesting as it marks a conceptual break with Migration Management. The 'tragedies at sea' are a visible symptom, and one that is not so easily ignorable, of those people suspended at the borders to the Global North. These people cannot be physically disappeared, even if they might have been conceptually disappeared. Migration

\footnotetext{
${ }^{47}$ Bigo, '(In)securitization Practices of the Three Universes of EU Border Control'.

${ }^{48}$ D. Bigo, 'Security and Immigration: Toward a Critique of the Governmentality of Unease', Alternatives: Global, Local, Political 27 (1 suppl.) (2002): 63-92, 65.

${ }^{49}$ P. Pallister-Wilkins, 'The Humanitarian Politics of European Border Policing: Frontex and Border Police', in International Political Sociology 9, no. 1 (2015): 53-69; ICMP Fact Sheet ICMP.Cos.58.9.eng.doc.

${ }^{50}$ European Council, 'The Stockholm Programme - An Open and Secure Europe Serving and Protecting Citizens', Official Journal of the European Union 2010/C 115/01, (2010), 28.
} 
Management largely reposed international migration as a question of capacity and privileged access, framing it as a potential security threat. This approach then finds it difficult to react to situations which directly question the security-framing it relies on. This is because it would have to conceptually undisappear the suspended and integrate what it radically excludes. The countries imposing Migration Management would have to acknowledge the people's juridico-political existence.

Tara Brian of the IOM writes in the executive summary of Fatal Journeys that 'globally, IOM estimates that at least 4,077 migrants died in 2014, and at least 40,000 since the year 2000 . The true number of fatalities is likely to be higher, as many deaths occur in remote regions of the world and are never recorded. ${ }^{51}$ The IOM notes that

no organization at the global level is currently responsible for systematically monitoring the number of deaths [...] Data tends to be scattered, with a range of organizations involved in tracking fatalities and often employing different definitions of border-related death. [...] In the case of tragedies at sea, the majority of bodies are often never found. As many migrants are undocumented, often relatively little is known about their identities. ${ }^{52}$

The discovery of migrants as 'fatalities' is recent. It reflects a conceptual and practical confusion about how to deal with illegal migrants who have been

\footnotetext{
${ }^{51}$ Brian and Laczko, Fatal Journeys, 11.

${ }^{52}$ Ibid.
} 
suspended - conceptually disappeared - but who have not died: those living rough at the external boundary to the European Union.

International organizations increasingly include the issue of migrants going missing as a result of their precarious journeys in their discussions and programme planning. The ICMP's narrative offers the following rationale for involvement:

Missing persons as a consequence of organized crime, Trafficking in Human Beings and migration are still an unknown quantity. The problem needs to be explored further, [...]. Furthermore, standardizing data processing, collection and analysis holds significant potential for making progress in this field. ${ }^{53}$

The need to make progress via standardisation and data collection and analysis was echoed - not for the first time - by the European Commission in a press release issued on 20 April 2015, in the context of the more recent deaths, when a ten-point plan on migration was issued to 'urgently' address 'the crisis'. ${ }^{44}$ Most of the ten points related to deterrence mechanisms through the use of (military) resources, but four related to the gathering and sharing of data, for example general data gathering in the context of asylum applications, including biometric data, tracing not only of the particular routes that migrants take but also of the funds of smugglers in order to 'extent the operational area' covered. This press

\footnotetext{
${ }^{53}$ ICMP, The Missing, 30.

${ }^{54}$ European Commission Joint Foreign and Home Affairs Council, Ten Point Action Plan on Migration IP/15/4813 (Luxembourg: European Commission, 2015).
} 
release again shows the conceptual muddle between addressing problems created by the fact of illegal migrants who have not died and the assumption of death as a driver for policy and practical considerations. Robins, Kovras, and Vallianatou argue that in Europe ' $[t]$ he discourse of securitisation of migration that leads to a delocalisation of the problem of migrant deaths at sea and the broader dehumanisation of migrants is responsible for both the deaths and official neglect of migrant bodies'. ${ }^{5}$ It seems that the recent deaths are numerically substantial enough for European Union countries to acknowledge that there is a problem.

In short, the dead migrant troubles the conceptual disowning of illegal migrants and demands justice; 56 in this way the dead problematize Migration Management's attempt to domesticate the unruly. Given this situation it might be justified to consider whether the humanitarian instinct around the reconceptualization of migrants into missing migrants might lead to a destabilisation of Migration Management.

\section{Destabilising Migration Management?}

\footnotetext{
${ }^{55}$ S. Robins, I. Kovras, and A. Vallianatou, 'Addressing Migrant Bodies on Europe's Southern Frontier', Working Papers in Conflict Transformation and Social Justice, CTSJ WP 05-14 (York and Belfast: Institute for the Study of Conflict Transformation and Social Justice, 2014), 4.

${ }^{56}$ ICMP, The Missing, 30.
} 
On the face of it, the humanitarian instinct might mellow the harsher effects of Migration Management. It could focus on the living, on protection. Thereby the management of the illegal migrant would be exposed as the regime of radical differentiation and exclusion by pointing to what is most problematic about it: policy making and enforcement to counter illegal migration is equivalent to enforced disappearance and a high probability of death. Migration Management built at the point of its inception in the 1980s and 1990s on a claim for urgency of action, and effectively securitised the phenomenon of international migration. ${ }^{57}$ Is a reconceptualization capable of changing the notion of urgency that is materialised in policy measures that will either disappear or kill the migrant, however sympathetic we might be for the families left behind?

Those academics and practitioners who call for a reconceptualisation of these travellers pose the dilemma for policy making of having to reverse the process that suspends migrants: 'Illegal migrants' have to be brought back into the fold of being given a legal status that is expressible on paper when, discursively and practically, it is these 'illegal migrants' who stabilize the notion that migration can be managed. What would be the effect of bringing illegals back into the fold? The effect is that illegal migrants need to be traced and identified. Security, writes Bigo

\footnotetext{
${ }^{57}$ Bigo, 'When Two Become One'.
} 
drawing on Squire, is not about stopping, but about following mobility. 58 Tracking migrants is technologically possible. Mobile phones regularly check in with their nearest antenna; smartphones do so 10 times per second. ${ }^{59}$ This means data can be obtained not only by accessing phone records, but also by companies logging which antenna has been contacted on a regular basis by a particular phone, even if it is not in use. ${ }^{60}$

One example of what might happen when tracing technology is used systematically relates to refugees living in camps, who are already registered and are in this sense not missing. The ICMP suggests drawing on and extending IOM's Displacement Tracking Matrix. To date, both the UNHCR and IOM register refugees by using biometric data: this is in order to avoid fraud in the context of, for example, food distribution. ${ }^{61}$ So far, it is said that this data is not shared with governments: not only for practical reasons, but also for ethical reasons. An IOM member of staff stated that they don't want to have a database with names, which could be sent to the wrong people. ${ }^{62}$ Yet, if authorities were to DNA-register displaced persons in

\footnotetext{
${ }^{58}$ Bigo, 'The (In)securitization Practices of the Three Universes of EU Border Control', 213. See Squire, ed., Contested Politics of Mobility.

${ }^{59}$ L. Taylor, No Place to Hide? The Ethics and Analytics of Tracking Mobility Using Mobile Phone Data (2014). Available at: http://bordercriminologies.law.ox.ac.uk/no-place-to-hide. Accessed 15 November 2014.

60 Ibid.

${ }^{61}$ Interview, IOM, Geneva, January 2015.

${ }^{62}$ Interview, IOM, Geneva, January 2015.
} 
refugee camps the effects could be devastating. ${ }^{63}$ Many refugee camps outside Europe have existed for a long time. ${ }^{64}$ Living conditions in such camps are difficult at best, so if people have the chance, they might understandably try to move on. However, if they are identified while trying to claim asylum in a European country, possibly after having been traced on their onward journey in another country, they would be unlikely to be granted protection.

The consequences of tracing, identifying and thus giving back political subjectivity to these travellers are indeed worrying given the European Union's track record on how it treats those who deviate from the norm. ${ }^{65}$ First, DNA specialists have explained that not only can illegal migrants be identified and this information be stored on databases for future reference and to monitor what happens to them much as the IOM monitors what happens to people it has registered in refugee camps - the biological relatives can be targeted based on information held in databases and matched as well. ${ }^{66}$ Second, tracking of migrants would mean not only that the routes the migrants travelled could be known, potentially in real time; it also would mean that individuals could be identified as most countries now

\footnotetext{
${ }^{63}$ I. Van der Ploeg, 'The Illegal Body: EURODAC and the Politics of Biometric Identification', Ethics and Information Technology 1, no. 4 (1999): 295-302.

${ }^{64}$ G. Loescher and J. Milner, 'The Missing Link: The Need for Comprehensive Engagement in Regions of Refugee Origin', International Affairs 79, no. 3 (2003): 595-617.

65 J. Huysmans, The Politics of Insecurity: Fear, Migration and Asylum in the EU (Routledge, 2006).

${ }^{66}$ Conference participant, 'An Agenda for the Future', ICMP, The Hague, 31 October 2013. Interview, ICMP Tuzla, June 2014.
} 
require that SIM cards are registered. In sub-Saharan Africa, for example, this is the case for 48 out of 50 countries. ${ }^{67}$

The example of refugees in camps and related tracing activities shows the extension of Bigo's category of data professionals involved in the management of migration: 'States have the will to control migration; corporations have the data. But the researchers who develop models and new analytical approaches are the essential third actor in these surveillant assemblages'. ${ }^{68}$ So, far from mellowing Migration Management, adding capacity to identify 'more accurate' data for identity management is likely to consolidate the devastating effects of Migration Management's radical violence of suspending people at its outer borders, whilst painting it over with a narrative of concern and care. Conceptually, such tracing and identifying efforts would mean a reversal of the suspension achieved in the process of sorting the entrepreneurial migrant from the irredeemable migrant. It would not be possible to maintain the hazy notion of the devious, poor black male: ${ }^{69}$ managers of migration would at least have to acknowledge the existence of such a suspended person. However, tracing and identifying would give data managers and migration experts an extended set of knowledges they could draw on to 'validate' their knowledges and legitimise practices of exclusion. It is in this

\footnotetext{
${ }^{67}$ Taylor, No Place to Hide?

${ }^{68}$ Ibid.

${ }^{69}$ Andersson, Illegality, Inc.
} 
sense that I argue that such a reconceptualisation cements, rather than disrupts, the discourse of Migration Management.

In this sense, not only is Migration Management the condition of possibility for the particular kind of illegal migration at external borders that defines the boundary between the rich and efficient and the poor and tired; but the reconceptualisation of illegal migrants into missing persons also establishes a new, possibly more potent and at the same time perverse boundary: that between those who live and those who die.

\section{Conceptual Innovations?}

Enforcement has 'the knowledge of computer systems, the capacity to create and manage, through [DNA analysis and] statistics, groups of populations - groups that are constituted through algorithms and profiling'. ${ }^{70}$ Bigo's research focuses on the algorithmic expression of the 'real' person and shows that a person with the right profile according to the 'normal' algorithm finds open doors. Those not fitting the right profile - by extension - might likely be those drawing on other means to migrate. From the perspective of the European Union and its composite parts, it is by way of these algorithms that stability is to be defined and enacted. Many

\footnotetext{
${ }^{70}$ Bigo, '(In)securitization Practices of the Three Universes of EU Border Control', 216.
} 
international professionals agree that 'forensic activities have become highly relevant also due to increasing numbers of migrant fatalities'. ${ }^{71}$

The framing logic of Migration Management materializes in detention camps in Mauritania and other countries of the African continent where people are abused to the point of death by neglect on the part of those policy makers in the Global North who pressure governments at the geopolitical fault lines to do their enforcement. ${ }^{72}$ Wilful killing also materialises in fences at strategic geopolitical boundaries, such as those at the Spanish exclave of Melilla. The 'fence' around Melilla is seen as an 'advanced security solution', considered a humane construct as it did not (at the time when it was installed) have razor wires. The fence bends 'outwards' and has a moveable pane on top to trap anyone who manages to climb up. The section between the fences consists of metal mesh which tenses upon contact, trapping whoever jumps or falls down on it. This 'humane' construct also boasts movement detectors, cameras and the capacity to spray peppered water in case of a bigger 'assault'. Such a construct may not rip a person open like razorwire fences do, but it is still capable of killing. Its construction was funded by the Spanish government and the European Union. ${ }^{73}$

\footnotetext{
${ }^{71}$ ICMP, The Missing, 30.

${ }^{72}$ Lucht, 'Pusher Stories'.

${ }^{73}$ Andersson, Illegality, Inc., 89-130.
} 
The framing logic is also adaptable to new technologies. ${ }^{74} \mathrm{New}$ technology involving DNA analysis could indeed be used to identify the many dead once they are recovered. A random search on the internet finds many stories of the dead. Worldwide, according to one study, the number of dead people believed to have fallen off airplanes as their undercarriage was opened in the process of landing has grown to 96 between 1947 and 2013.75 Yet, 96 dead bodies are insignificant when compared with a US study, in which researchers counted 2,238 deaths in Pima County, Arizona, alone over the past decade and a half. This was a project which used DNA profiling and identification mechanisms in order to give people a name. The research reported that only 34 per cent of the migrants found dead remain unidentified. ${ }^{76}$ The number of people dying on their way to Europe remains uncounted..$^{77}$

A focus on the dead is relevant because 'the missing have greater symbolic facticity than the dead', as explained by Sant Cassia. ${ }^{78}$ Thinking about missing persons in the context of Cyprus, Sant Cassia sets out to show how the Greek Cypriots and the

\footnotetext{
${ }^{74}$ Bigo, 'The (In)securitization Practices of the Three Universes of EU Border Control', 218.

75 J. Kelly, 'How Often Do Plane Stowaways Fall from the Sky?' Guardian, 14 September 2013. Available at www.bbc.co.uk/news/magazine-19562101. Accessed 28 December 2013.

${ }^{76}$ Binational Migration Institute, A Continued Humanitarian Crisis at the Border: Undocumented Border Crosser Deaths Recorded by the Pima County Office of the Medical Examiner, 1990-2012 (University of Arizona, 2013).

77 J. Carling, 'Migration Control and Migrant Fatalities at the Spanish-African Borders', International Migration Review 41, no. 2 (2007): 316-43.

${ }^{78}$ P. Sant Cassia, Bodies of Evidence: Burial, Memory and the Recovery of Missing Persons in Cyprus (New York: Berghahn, 2005).
} 
Turkish Cypriots differently make use of 'their' missing in their practices of boundary drawing and maintenance. What is important here is that, the Greek Cypriot missing are constructed as deferred political subjectivities - they symbolise existence - whilst the Turkish authorities have constructed their dead as lost and gone. ${ }^{79}$ Sant Cassia writes that 'borders are first and foremost symbolic boundaries, whose transgression is signalled by the production of dead bodies [...], and their post-mortem treatment'. ${ }^{80}$ Both constructions distort and exploit, the manipulation of the dead as pure objects ultimately sanctions power by differentiation between dead and alive: the dead are recovered as numbers and bodies to be put into the ground, in this way confirming their new citizenship, as in the Italian case cited at the start of this article. The political subjectivity of those missing migrants is deferred as data in databases: not (yet) dead, not (yet) citizens. This deferral, though, is no less important as it legitimises the paradigmatic working of Migration Management. Migration Management, as a result, will not only be consolidated in both logic and approach. By conceptually innovating and constructing the missing migrant, the border becomes one between those who are

\footnotetext{
${ }^{79}$ Ibid., 119.

${ }^{80}$ P. Sant Cassia, 'Guarding Each Other’s Dead, Mourning One’s Own: The Problem of Missing Persons and Missing Pasts in Cyprus’, South European Society and Politics 11, no. 1 (2006): 111-28, 15.
} 
alive and those who are dead - pure objects to be made use of politically as Migration Management reinvents its maintenance of a stable order. ${ }^{81}$

\section{Conclusion}

In this article, I have identified a move to reconceptualise illegal migrants in policy and academic debates and practice as 'missing persons'. On first inspection, reconceptualising illegal migrants into missing persons might be seen as leading to a destabilisation of the more violent exclusionary traits of Migration Management via making authorities more accountable. However, I argue that this regime of radical exclusion is not destabilised by conceptual innovation; on the contrary, there is a significant risk that the move will endanger those suspended. The identification of bodies, via biometrics and DNA analysis, emphasises the deferral of personhood and cements the violent traits of Migration Management for those alive even further.

Indeed, the conceptual innovation of 'missing migrants' raises questions about the ethical integrity of European governance systems, precisely because the reconceptualization constitutes a redrawing of boundaries between the dead and the living which does not challenge negligence leading to death. Can we still think

\footnotetext{
${ }^{81}$ Stepputat, Governing the Dead.
} 
in terms of 'protection', rather than covering over the ruptures and defeating the moral rights that we have given ourselves and that we regularly make use of as a standard when interacting with other parts of the world? Such a reconceptualisation might bring relief to those families who have lost a person in the process of migration; however, those who advocate for this way of understanding illegal migrants need to be careful about what effects such new knowledge brings to those (still) living.

What is at stake here is that the policies responsible for these deaths have been made and implemented by European governments and agencies at the external borders of the EU. Yet the blame is placed on smugglers and traffickers, without any discussion of the fact that it was these same governments that criminalised smuggling and trafficking in the first place in 2001 - or reflection on European government's practices which have meant an active undermining of the 1951 Refugee Convention and any attempt at a functioning asylum system. If a destructive regime, like that of Migration Management, is to be destabilized a change in register needs to be made. Conceptual innovations that accept the hegemonic frame of reference, which in turn set the standard for intelligibility, will fail to constructively undermine the perverse effects of Migration Management.

\section{References}


M. Agier. "Humanity as an identity and its political effects (a note on camps and humanitarian government)." Humanity: An International Journal of Human Rights, Humanitarianism, and Development 1, no. 1 (2010): 29-45.

L. Amoore, 'Biometric Borders: Governing Mobilities in the War on Terror', Political Geography 25, no. 3 (2006) : 336-51.

R. Andersson, Illegality, Inc.: Clandestine Migration and the Business of Bordering Europe (Oakland: University of California Press, 2014).

I. Ashutosh and A. Mountz, 'Migration Management for the Benefit of Whom? Interrogating the Work of the International Organization for Migration', Citizenship Studies 15, no. 1 (2011): 21-38.

D. Bigo, 'When Two Become One: Internal and External Securitisations in Europe', in International Relations Theory and the Politics of European Integration, Power, Security and Community, eds. M. Kelstrup and M. C. Williams (London: Routledge, 2000).

D. Bigo, 'Security and Immigration: Toward a Critique of the Governmentality of Unease', Alternatives: Global, Local, Political 27 (1 suppl.) (2002): 63-92.

D. Bigo, 'The (In)securitization Practices of the Three Universes of EU Border Control: Military/Navy - Border Guards/Police - Database Analysts', Security Dialogue 45, no. 3 (2014): 209-25.

Binational Migration Institute, A Continued Humanitarian Crisis at the Border: Undocumented Border Crosser Deaths Recorded by the Pima County Office of the Medical Examiner, 1990-2012. Report (University of Arizona, 2013).

P. Boss, 'Ambiguous Loss in Families of the Missing', The Lancet 360 (suppl.) (2002): 39-40.

T. Brian and F. Laczko, Fatal Journeys: Tracking Lives Lost during Migration (Geneva: International Organization for Migration, 2014)

J. Butler, Precarious Life: The Powers of Mourning and Violence (London: Verso, 2006).

J. Carling, 'Migration Control and Migrant Fatalities at the Spanish-African Borders', International Migration Review 41, no. 2 (2007): 316-43. 
M. Crettol and A.-M. La Rosa, 'The Missing and Transitional Justice: The Right to Know and the Fight against Impunity', International Review of the Red Cross 88, no. 862 (2006).

G. Deleuze, Gilles, and F. Guattari. What is philosophy?. Columbia University Press, 2014.

J. Derrida. Limited inc. Vol. 10. Northwestern University Press, 1977.

J. Edkins, Missing: Persons and Politics (Ithaca, NY: Cornell University Press, 2011).

European Commission Joint Foreign and Home Affairs Council, Ten Point Action Plan on Migration IP/15/4813 (Luxembourg: European Commission, 2015).

European Council, 'The Stockholm Programme - An Open and Secure Europe Serving and Protecting Citizens', Official Journal of the European Union 2010/C 115/01, (2010).

D. Fassin, Humanitarian reason: a moral history of the present. Univ of California Press, 2012.

X. Ferrer-Gallardo and H. van Houtum, 'The Deadly EU border control', ACME: An International E-Journal for Critical Geographies 13, no. 2 (2014): 295-304.

G. Garelli and M. Tazzioli, 'Arab Springs Making Space: Territoriality and Moral Geographies For Asylum Seekers in Italy', Environment and Planning D: Society and Space 31, no. 6 (2013): 1,004-21.

M. Geiger and A. Pécoud, The Politics of International Migration Management (Basingstoke: Palgrave Macmillan, 2010).

B. Gosh, Managing Migration: Time for a New International Regime? (Oxford: Oxford University Press, 2000).

S. Grant, 'Recording and Identifying European Frontier Deaths', European Journal of Migration and Law 13, no. 2 (2011): 135-56.

D. Groome, 'Right to Truth in the Fight against Impunity', Berkeley Journal of International Law 29 (2011): 175.

J. Huysmans, The Politics of Insecurity: Fear, Migration and Asylum in the EU (London: Routledge, 2006). 
J. Huysmans, 'What's in an Act? On Security Speech Acts and Little Security Nothings', Security Dialogue 42, nos. 4-5 (2011): 371-83.

International Commission on Missing Persons, The Missing - An Agenda for the Future, conference report (Sarajevo/The Hague: ICMP, 2013).

International Commission on Missing Persons, 'Technical Assistance' (n.d.). Available at www.icmp.org/what-we-do/technical-assistance. Accessed 5 December 2014.

International Commission on Missing Persons, ICMP Fact Sheet ICMP.Cos.58.9.eng.doc (n.d.). Available at: www.icmp.org/wpcontent/uploads/2013/10/icmp-cos-58-10-doc-fact-sheet.pdf (accessed 22 February 2014).

C. Jennings, Bosnia's Million Bones: Solving the World's Greatest Forensic Puzzle (Basingstoke: Macmillan, 2013)

H. Johnson, "The Other Side of the Fence: Reconceptualizing the "Camp" and Migration Zones at the Borders of Spain', International Political Sociology 7, no. 1 (2013): 75-91.

K. T. Jones, K. S. Zagacki, and T. V. Lewis, 'Communication, Liminality, and Hope: The September 11th Missing Person Posters', Communication Studies 58, no. 1 (2007): 105-21.

A. Kelly, 'Living Loss: An Exploration of the Internal Space of Liminality', Mortality: Promoting the Interdisciplinary Study of Death and Dying 13, no. 4 (2008): 335-50.

J. Kelly, 'How Often Do Plane Stowaways Fall from the Sky?' Guardian, 14 September 2013. Available at: www.bbc.co.uk/news/magazine-19562101. Accessed 28 December 2013.

E. Kirchbichler, 'Those Who Never Make It and the Suffering of Those Left Behind: The Fate of Honduran Missing Migrants and Their Families', Encuentro 42, no. 87 (2010): 61-74.

M. Koskenniemi, 'International Law and Hegemony: A Reconfiguration', Cambridge Review of International Affairs 17, no. 2 (2004): 197-218. 
G. Loescher and J. Milner, 'The Missing Link: The Need for Comprehensive Engagement in Regions of Refugee Origin', International Affairs 79, no. 3 (2003): 595-617.

H. Lucht, 'Pusher Stories: Ghanaian Connection Men and the Expansion of the EU's Border Regimes into Africa', in,The Migration Industry and the Commercialization of International Migration, eds. T. Gammeltoft-Hansen and N. Nyberg Sorensen (London: Routledge, 2013).

S. Mezzadra and S. Nielson, Border as Method: or, The Multiplication Of Labor (Durham, NC: Duke University Press) 2013.

C. Oelgemöller, 'Informal Plurilateralism: The Impossibility of Multilateralism in the Steering of Migration', British Journal of Politics and International Relations 13 no. 1 (2011): 110-26.

C. Oelgemöller, The Evolution of Migration Management in the Global North (Oxon: Routledge) 2017.

P. Ordaz, 'Solo los muertos pueden quedarse', El Pais, 5 October 2013. Available at http://internacional.elpais.com/internacional/2013/10/05/actualidad/13809995 28_613934.html. Accessed 22 February 2014.

P. Pallister-Wilkins, 'The Humanitarian Politics of European Border Policing: Frontex and Border Police', International Political Sociology 9, no. 1 (2015): 53-69.

E. Prokkola, 'Technologies of Border Management: Performances and Calculations of Finnish/Schengen Border Security', Geopolitics 18, no. 1(2013): 77-94.

S. Robins, I. Kovras, and A. Vallianatou, 'Addressing Migrant Bodies on Europe's Southern Frontier', Working Papers in Conflict Transformation and Social Justice, CTSJ WP 05-14 (York and Belfast: Institute for the Study of Conflict Transformation and Social Justice, 2014).

P. Sant Cassia, Bodies of evidence: Burial, memory and the recovery of missing persons in Cyprus (New York: Berghahn Books, 2005).

P. Sant Cassia, 'Guarding Each Other's Dead, Mourning One’s Own: The Problem of Missing Persons and Missing Pasts in Cyprus', South European Society and Politics 11, no. 1 (2006): 111-28. 
V. Squire, ed., The Contested Politics of Mobility: Borderzones and Irregularity (Basingstoke: Palgrave Macmillan, 2011).

L. Taylor, No Place to Hide? The Ethics and Analytics of Tracking Mobility Using Mobile Phone Data (2014) . Available at:

http://bordercriminologies.law.ox.ac.uk/no-place-to-hide. Accessed 15 November 2014

The Guardian (10 June 2001) ‘Fishermen's Net Haul in Secrets of Immigrant ‘Ship of Death'. Available at www.guardian.co.uk/world/2001/jun/10/davidrose.rorycarroll. Accessed 13 June 2010.

The Guardian (12 October 2013) 'Death Toll of African Migrants Rises after Boat Disaster near Lampedusa'. Available at www.theguardian.com/world/2013/oct/12/african-migrants-boat-lampedusacapsizes-mediterranean. Accessed 16 October 2013.

United Nations, Promotion and Protection of All Human Rights, Civil, Political, Economic, Social and Cultural Rights, Including the Right to Development. Report of the Special Rapporteur on the Human Rights of Migrants Jorge Bustamante A/HRC/7/12 (Geneva: Human Rights Council, 2008).

United Nations Security Council The Rule of Law and Transitional Justice in Conflict and Post-Conflict Societies. Report of the Secretary General S/2004/616* (2004). www.ipu.org/splz-e/unga07/law.pdf. Accessed 25 February 2016.

I. Van der Ploeg, 'The Illegal Body: EURODAC and the Politics of Biometric Identification', Ethics and Information Technology 1, no. 4 (1999): 295-302.

H. van Houtum, 'Human Blacklisting: the global apartheid of the EU's external border regime Environment and Planning D: Society and Space 28, no. 6 (2010): 957-76.

W. Walters, 'Mapping Schengenland: Denaturalizing the Border', Environment and Planning D: Society and Space 20, no. 5 (2002): 564-80. 
W. Walters, 'Foucault and Frontiers: Notes on the Birth of the Humanitarian Border', in Governmentality: Current Issues and Future Challenges, eds. U. Broeckling, S. Krasmann and T. Lemke (London: Routledge, 2011). 